\title{
Determining infants' age for measles vaccination based on persistence of protective level of maternal measles antibody
}

\author{
Tanjida Shilpi, Humayun Sattar and Md. Ruhul Amin Miah \\ Department of Microbiology and Immunology, Bangabandhu Sheikh Mujib Medical University, \\ Shahbag, Dhaka, Bangladesh.
}

\begin{abstract}
The present study was conducted over a period of one year to find the right time for measles vaccination when maternal antibody titer in infants was decayed rendering them susceptible to wild virus infection. Blood samples were collected from the cord of new born (147), 2-5 months (47) and 5 to 7.5 months (24) of age. The mean measles IgG antibody titer detected in cord blood at birth (0 months) was $348.8 \mathrm{mIU} / \mathrm{mL}$ which steeply decreased to $155.6 \mathrm{mIU} / \mathrm{mL}$ by the age of 23 months. After that the fall in antibody becomes relatively slower and decreased to 101.6 $\mathrm{mIU} / \mathrm{mL}$ by the age of $3-5$ months and $38.8 \mathrm{mIU} / \mathrm{mL}$ by the age of $5-6$ months and to 19.2 $\mathrm{mIU} / \mathrm{mL}$ between the age of 6 to 7.5 months. The fall in antibody level with the advance of age was statistically significant $(\mathrm{p}<0.001)$. Majority of the subjects $(97.6 \%)$ exhibited protective level of antibody at birth. But only a little above one-quarter (25.5\%) of them persisted the protective level between the age of 2-5 months and none had protective level from 5 months onwards.
\end{abstract}

\section{Introduction}

Measles is one of the most contagious respiratory diseases. It is a human disease of no known animal reservoir, and it is transmitted primarily from person-to-person through large respiratory droplets and also by aerosolized droplet nuclei ${ }^{1,2}$. The common complications of measles are otitis media (7-9\%), pneumonia (1- 6\%), post-infection encephalitis 1,000 to $1 / 2000$ cases), subacute sclerosing panencephalitis (SSPE) $(1 / 100,000$ cases). The mortality rate is $1 / 10,000$ cases with young children being the common victim ${ }^{1}$. Infants in developing countries become susceptible to measles infection at younger ages than do infants in the nations with good health care. Maternally acquired antibodies against measles (measles maternal antibody, MMA) lower in the newborn, may be responsible for the susceptibility to measles infection in infants from low-income regions ${ }^{34}$. Researchers have speculated on various factors to explain differences in the rates of decay of MMA between countries with incidences of diarrhea and respiratory infections and catabolic rate of
IgG. In rural Mali, the window of vulnerability of wild type measles among infants show absence of protective antibody between 6 to 9 months, while $30 \%$ had protective antibody between 2 to 6 months and again protective antibody appear at 9 months in $16 \% \%^{5}$. A similar picture was also reported from Saudi-Arabia with 33\% infants showing protective antibody level at 6 months while $36 \%$ lost antibody against measles at 9 months ${ }^{6}$. Similarly a dramatic decrease in measles cases was reported in Florida, USA by giving a second dose of MMR at 12 months ${ }^{7}$.

Therefore in determining the age for vaccination, countries must balance the consequences of an older age (lack of protection in the early months of life) and a younger age (reduce effectiveness). Many countries, where morbidity and mortality due to measles are uncommon in infants, an older age for vaccination is chosen (12-15 months). In other countries, where morbidity is more or less common a younger age $(<9$ months $)$ for vaccination, has been advocated ${ }^{8}$. Given this situation, the present study was conducted to find out the appropriate time where maternal antibody 
titre in infants is being cleared and become susceptible to measles infection.

\section{Materials and Methods}

This prospective study was conducted on pregnant mothers admitted at BSMMU, Ad-Din Hospital and ICMH and their babies from birth to $6^{\text {th }}$ months of age over a period of 1 year. Healthy pregnant mothers before delivery and their babies with weight $>2 \mathrm{~kg}$ and APGAR score $>7$ at birth were included in the study. Mothers with hypertension, diabetics and chronic systemic diseases were excluded from the study. Having written consent obtained from the study subjects interview was conducted. Information regarding their health and pregnancy was recorded on a pre-designed data sheet. $3 \mathrm{~mL}$ of venous blood samples were collected from each of 157 mothers ( $1^{\text {st }}$ sample). Similarly, cord blood samples were collected from their offsprings $\left(1^{\text {st }}\right.$ sample) and preserved properly. All the samples of mothers were tested for measles antibody. At the time of $2^{\text {nd }}$ sample collection a total of 47 infants at the age 2 months to 4.5 months and their mothers' blood were taken. To observe the dynamics of measles IgG antibody level of the baby from birth onward, $1^{\text {st }}$ samples of the same children were taken into account. Lastly, a total of 24 children venous blood ( $3^{\text {rd }}$ sample) were collected at 5 to 7.5 months of age. All serum samples after being separated from blood were stored at $20^{\circ} \mathrm{C}$ until use.

Quantitative estimation of measles specific IgG antibody was carried out by ELISA method (Human Biomedica, Germany). The protective level of measles IgG antibody titer was 200 $\mathrm{mIU} / \mathrm{mL}$. A blue color developed changing to yellow after stopping the reaction. The intensity of color is directly proportional to the measles antibody concentration in the specimen. Dilution of the patient's sera $1+100$ with dilution buffer IgG (DIL-G) e.g. $10 \mu \mathrm{L}$ serum $+1 \mathrm{~mL}$ dilution buffer IgG (DIL-G) and was mixed thoroughly. Adhesive strips were removed and the contents of the microtiter wells were aspirated off into $5 \%$ sodium hypochlorite solution and $350 \mu \mathrm{L}$ washing solution was added to each well, aspirated off after $30 \mathrm{sec}$ soak time and was repeated again. All reagents and micro-wells were brought at room temperature $\left(15-25^{\circ} \mathrm{C}\right)$ before use. Desired number of strips and strip retainer were removed from the sealed plastic package. Unused strips were replaced back in the pouch with desiccant and were sealed tightly.

Calculation of control values and cut-off: Mean absorbance values of $\mathrm{NC}$ in wells $\mathrm{Bl}$ and $\mathrm{Cl}$ (MNC) and $\mathrm{PC}$ in wells $\mathrm{Dl}$ and $\mathrm{El}$ (MFC) were calculated according to $\mathrm{MNC}=\left[\mathrm{A}_{450}(\mathrm{~B} 1)+\mathrm{A}_{450}(\mathrm{C} 1)\right] / 2$; MPC $=\left[\mathrm{A}_{450}(\mathrm{D} 1)+\mathrm{A}_{450}(\mathrm{E} 1)\right] / 2$; Cut-off value $(\mathrm{COV})=\mathrm{MNC}+0.1 \times \mathrm{MPC}$. The test run were considered valid as the following criteria were metsubstrate blank in the well A1 $<0.150$, MNC $\leq 0.250$, MFC $\geq 0.750$ and MPC: $\mathrm{MNC} \geq 5$.

The result was interpreted as $\mathrm{A}_{450}$ (patient) COV$15 \%$ anti-MV-IgG-Ab positive and $\mathrm{A}_{450}$ (patient) $\mathrm{COV}-15 \%$ anti-MV-IgG-Ab negative.

\section{Result}

The mean measles IgG antibody titer detected in cord blood at birth was $348.8 \mathrm{mIU} / \mathrm{mL}$ which steeply decreased to $155.6 \mathrm{mIU} / \mathrm{mL}$ by the age of 2-3 months (Figure 1). After that the fall in antibody becomes relatively slower and decreased to 101.6 by the age of 3-5 months and $38.8 \mathrm{mIU} / \mathrm{mL}$ by the age of $5-8$ months. The antibody level further reduced to $19.2 \mathrm{mIU} / \mathrm{mL}$ between the age of 6-7.5 months.

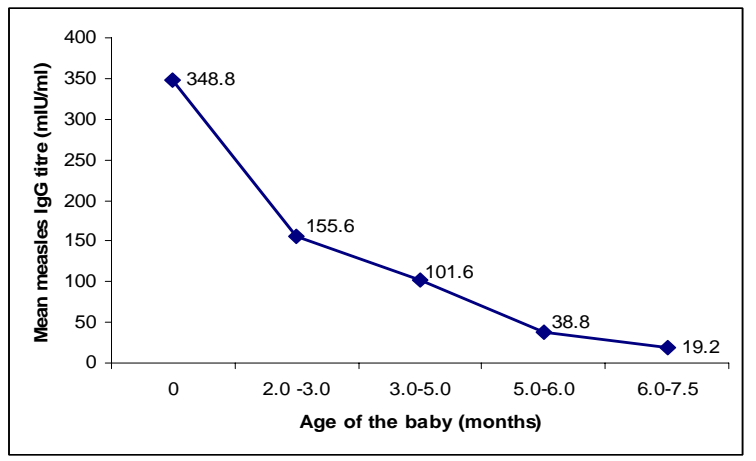

Figure 1: Changes in measles IgG antibody level of babies with advance age

The mean measles IgG antibody in the cord blood decreased to $128.9 \mathrm{mIU} / \mathrm{mL}$ in the $2^{\text {nd }}$ sample of blood taken between the age of 2-5 months and $33.6 \mathrm{mIU} / \mathrm{mL}$. The fall in antibody level with the advance of age is statistically significant $(p<0.001$; Table I). Majority of the subjects $(97.6 \%)$ exhibited protective level of antibody (measles $\mathrm{IgG} \geq 200 \mathrm{mIU} / \mathrm{mL}$ ) at birth. But only $25.5 \%$ of them persisted the protective level between the age of 2-5 months and none had protective level from 5 months onwards (Table II). 
Table I: Comparison of measles IgG antibody titer among different blood samples

\begin{tabular}{lcc}
\hline Blood samples of babies* & $\begin{array}{c}\text { Measles IgG } \\
\text { antibody titre }\end{array}$ & $\begin{array}{c}\mathrm{p} \\
\text { value }\end{array}$ \\
\hline $1^{\text {st }}$ sample (cord blood) & $348.8 \pm 57.3$ & \\
$2^{\text {nd }}$ sample (age 2-5 months) & $128.9 \pm 81.4$ & $<0.001$ \\
$3^{\text {rd }}$ sample (age 5 - 7.5 months) & $33.6 \pm 13.3$ &
\end{tabular}

*Data were analyzed using ANOVA statistics and were presented as mean $\pm \mathrm{SD}$

Table II: Protective level of measles IgG antibody at different ages

\begin{tabular}{lccc}
\hline $\begin{array}{l}\text { Blood samples of babies at } \\
\text { different age }\end{array}$ & $\mathrm{n}$ & \multicolumn{2}{c}{$\begin{array}{c}\text { Protective level of } \\
\text { measles IgG antibody } \\
(\geq 200 \mathrm{mIU} / \mathrm{mL})\end{array}$} \\
\cline { 2 - 4 } & & Frequency & $\%$ \\
\hline $1^{\text {st }}$ sample (cord blood) & 47 & 147 & 97.8 \\
$2^{\text {nd }}$ sample (age 2 -5 months) & 47 & 12 & 25.5 \\
$3^{\text {rd }}$ sample (age 5-7.5 months) & 24 & 00 & 0.0 \\
\hline
\end{tabular}

Data were analyzed using ANOVA statistics and were presented as mean $\pm \mathrm{SD}$

\section{Discussion}

This study was carried out to evaluate the measles IgG antibody status in infants below vaccination age in relation with a view to find out the window of vulnerability where infants are exposed before the recommended age of vaccination. This is necessary because after the introduction of measles vaccination in Bangladesh in 1980 under EPI, a dramatic decline in measles cases was observed and continued till 2003, but the number of measles cases again started increasing from 2004 onwards, though the immunization coverage increased from $65 \%$ in 1990 to $76 \%$ in 2004 . Some developing countries like Guinea Bissau, Kinshasa, Mali and others have rescheduled measles vaccination at 6 months of age. This change of policy has brought in favorable results with a visible decline in measles cases and deaths ${ }^{5}$.

The drastic fall of antibody titer between ages 25 months compared to that observed in cord blood have also been reported by Milagritos et al and could be explained partly by its half life phenomenon and partly by neutralization mechanism $^{5}$. Measles antibody belongs to $\operatorname{IgG}$ with a half life of $35-45$ days. So, $50 \%$ of the antibody acquired passively from the maternal blood decayed as the child reaches the age of 2 months. Another fall could be attributed to neutralization mechanism caused by exposure of the child to wild virus ${ }^{10}$. Among 47 cord blood samples, $46(97.8 \%)$ had protective level of antibody at birth. But only $25.5 \%$ of them persisted the protective level between the age of 2-5 months and none had protective level beyond 5 months of age. In a similar study in Mali, the window of vulnerability as detected by the absence of measles IgG antibody was found to begin at 2 months of age and extended up to nine months of age. At 2 months of age 30\% had protective titer and at 6 months of age none had protective titer (by PRN and ELISA). Another study intended to measure maternal measles antibody decay in rural Bangladesh was done in 1994. The study reported that by the age of 5 months $67 \%$ (28/42) of infants had practically no protective antibody left. Only $12 \%$ infants at 5 months of age and $5 \%$ at 8 months had protective level of antibody ${ }^{11}$. This study also used PRN assay and ELISA to detect the antibody. A longitudinal study was done on Black South African infant measured the loss of maternal measles antibody in order to find the necessity of measles vaccination before the age of 9 months.

The study revealed that majority (88\%) of 6 months old infants were unprotected against measles, while at 9 months all were susceptible ${ }^{12}$. In a Turkish study infants seropositive for measles antibody at 6 and 9 months of ages were found to be $61.8 \%$ and $3.4 \%$ respectively suggesting that the measles vaccination could be carried out earlier than just before the critical age of antibody level ${ }^{13}$.

From the findings of the present study it seems that measles vaccination could be carried out before the age of 6 months. However, the sample size of the present study was too small to generalize the findings to reference population. A large scale study is, therefore, recommended and on the basis of the findings derived from the study, measles vaccination could be rescheduled if needed.

\section{References}

1. Black FL. The role of hard immunity in the control of measles. Yale J Biol Med. 1982; 55: 352-60.

2. Bloch AB, Orenstein WA, Ewing WM. Measles outbreak in a paediatric practice: Airborne transmission in a office setting. Paediatrics 1985; 75: 676-83. 
3. Preblud SR, Katz SL. Measles vaccine. In: Vaccines. Plotkin SA, Mortimer EA (eds). London, WB Saunders, 1988.

4. Vasiber AOJ, Hernandej H, Guillen D, Chu P, Colarossi A. Loss of maternally acquired antibody to measles in wellnourished infants and response to measles vaccination, Peru. AJPH. 1990; 80: 736-37.

5. Milagriots DT, Sambia OS, Sandara MM, Yu L, Marcela FP, Karen K et al. Serosurvey to identify the window of vulnerability to wild-type measles among infants in rural Mali. Am J Trop Med. 2005; 73: 26-31.

6. Khalil MK, Al-Mazrou YY. Measles immunization in Saudi Arabia: the need for change. Eastern Mediterranean Health J. 2001; 7: 829-34.

7. Hutchins SS, Dezayas A, Blond KL, Heath J, Bellini W, Audet S, Beeler J, Wattigney W, Markowitz L. Evaluation of an early two-dose measles vaccination. Am J Epidemiol. 2001; 154: 1064-71.

8. Sutter CS. Prevalence of measles maternal antibody. Clin Infec Dis. 2000; 3: 110-17.
9. WHO. EPI Fact Sheet, Bangladesh, 2004. http://www.searo.who.int/mediacenter/factsheets/fs286/en/

10. Victor MC, Peter MS, Roland WS. Factors determining prevalence of maternal antibody to measles virus throughout infancy: A review. Clin Infec Dis. 2000; 31: $110-19$.

11. de Franscisco A, Hall AJ, Unicomb L, Chakrobarti J, Yunus M, Sack RB. Maternal measles antibody decay in rural Bangladeshi infants: Implications for vaccination schedules. Vaccine 1998; 16: 564-68.

12. Kiepiela P, Kvadia HM. Loss of maternal measles antibody in black South African infants in the first year of life: Implication for age of vaccination. S Afr Med J. 1991; 79: $145-48$.

13. Altinuts DU, Evliyaoglu N. The modification in measles vaccination age as a consequence of the earlier decline of transplacentally transferred anti-measles antibodies in Turkish infants. Eur J Epidemiol. 1996; 12: 647-48. 